\title{
International Experience of the U.S. Bureau of Alcohol, Tobacco and Firearms Operation (Civil Law and Criminal Law Relationship)
}

\begin{abstract}
Kofanov Andrii
Legal Advisor to the Council of Europe Programme "Decentralization and Territorial Consolidation in Ukraine”, PhD of Juridical Sciences, Associate Professor, Professor of Department of Forensic Support and Forensic Expertise of the National Academy of Internal Affairs, Kiev, Ukraine ORCID ID 0000-0002-5242-2518_kofanov_andrey@ukr.net
\end{abstract}

\begin{abstract}
Atamanchuk Volodymyr
PhD of Juridical Sciences, Chief of Department of Forensic Support and Forensic Expertise of the National Academy of Internal Affairs, Kiev, Ukraine ORCID ID 0000-0002-1464-7871 atamanchykvlad@ukr.net
\end{abstract}

\section{Kravchuk Oleh}

Candidate of Juridical Sciences, Associate Professor of the Department of Criminal Procedural Law of Khmelnytsky University of Management and Law, Khmelnytskyi, Ukraine ORCID ID 0000-0002-7002-4070 olega_kravchuk@ukr.net

\section{Pavlovska Nataliia}

PhD of Juridical Sciences, Associate Professor, Professor of Department of Civil Law and Process of the National Academy of Internal Affairs, Kiev, Ukraine ORCID ID 0000-0003-3311-0364 wwwpav@gmail.com

\section{Metil Anastasiia}

Candidate of Juridical Sciences, Senior Lecturer on Faculty of Ukrainian Philology and Social Sciences of Izmail State University of Humanities, Izmail, Ukraine

ORCID ID 0000-0002-9197-3937 Metilnasty1@ gmail.com

\footnotetext{
Abstract

The U.S. Bureau of Alcohol, Tobacco and Firearms (ATF) is a tax-collecting, enforcement and regulatory arm of the U.S. Department of the Treasury [2, pp. 1-7]. In common with all other members of the executive branch, ATF's responsibility is established by congressional action. ATF cannot enact a law, nor can it amend the law. Charged as it is with fiscal oversight of some of the most controversial topics in Western civilization, ATF strives to maintain professional neutrality while giving a 35-to-1 return on every dollar it spends. ATF has the best cost-to-collection ratio in the federal family.

ATF is the youngest tax-collecting Treasury agency, separated from the Internal Revenue Service by
} 
Treasury Department Order No. 120-1 (former No. 221), effective 1 July 1972. Notwithstanding, ATF traces its roots across two hundred years of American history.

Keywords: key provisions of U.S. laws regulating firearms; legal and institutional tools to monitor transactions between states, monitor transactions between countries; accounting and reporting of manufacturing, importing and dealing in firearms.

Introduction In 1789 under the new Constitution [1, pp. 19-21], the first Congress imposed a tax on imported spirits to offset a portion of the Revolutionary War debt assumed from the states. Administration of duties fell to the Department of the Treasury, whose Secretary, Alexander Hamilton, had suggested them. Congressional lawmakers were favorably impressed by the results. The imports tax was augmented by one on domestic production in 1791. Taxpayers had grumbled over import duties, while some of them greeted the domestic levy - as they do today — with political resistance, escalating in that early case to the shortlived Whisky Rebellion of 1794. Both revenue sources survived rebellion - as they do today. Although these particular taxes were eventually abolished, similar devices for revenue came and went as needed until 1862. By Act of 1 July 1862, Congress created an Office of Internal Revenue within the Treasury Department, charging the commissioner with collection, among others, of taxes on distilled spirits and tobacco products that continue, with amendments, today [6]. Because taxation so often does evoke public resistance, including criminal evasion, during 1863 Congress authorized the hiring by Internal Revenue of "three detectives to aid in the prevention, detection and punishment of tax evaders." Tax collecting and enforcement were now under one roof. Before decade's end, the Office of Internal Revenue had its own counsel, another component descending in unbroken line to ATF today.

In 1875, federal investigators broke up the "Whiskey Ring", an association of grain dealers, politicians and revenue agents that had defrauded the government of millions of dollars in distilled spirits taxes. Responding to the snowballing scandal, Congress undertook the first Civil Service reform acts, acknowledging formally that effectiveness of law depends on the quality of its administrators.

The commissioner's annual report for 1877 refers to his office as the Bureau of Internal Revenue, a title that it retained for the next seventy-five years. In 1886, a single employee from the Department of Agriculture came to the Bureau of Internal Revenue under authority of the Oleomargarine Act to establish a Revenue Laboratory [6]. The first samples received in the laboratory that 29 December were of butter suspected of adulteration with oleomargarine. In its second century, ATF's laboratory staff includes — but is not limited to - chemists, 
document analysts, latent print specialists, and firearms and toolmark examiners, supported by its own highly sophisticated facilities at Rockville, Maryland, Atlanta, Georgia, and Walnut Creek, California [7-11]. That first chemist would recognize some aspects of laboratory service today (analysis of alcohol and tobacco products, for instance) although tools such as chromatography and electrophoresis might seem magic. There was nothing in 1886 to foreshadow the Laboratory's sought-after forensic skills in arson, explosives, and criminalevidence examination, a resource now available to law enforcement personnel worldwide [7$11]$.

Ratification of the Eighteenth Amendment to the Constitution in 1919, in combination with the Volstead Prohibition Enforcement Act of that year, brought to prominence those officers - "revenoors" - charged with investigating criminal violations of the Internal Revenue law, including illicit manufacture of liquors. By early 1920, these experts coalesced into the Prohibition Unit. Evolution of this unit reflects the difficulty of enforcing a nationwide ban on "manufacture, sale or transportation of intoxicating liquors for beverage purposes." Internal Revenue's orientation has been toward collection throughout its history. Enforcement efforts, albeit necessary, never came easily. On 1 April 1927, Treasury elevated the Prohibition Unit to bureau status within the department. Congress was impatient with the results. On 1 July 1930, Congress transferred "the penal provisions of the national prohibition act" from Treasury's Bureau of Prohibition (which then ceased to exist) to the Department of Justice's new Bureau of Prohibition — with an important exception: tax-related and regulatory activities, "the permissive provisions," remained at Treasury, under a new Bureau of Industrial Alcohol. The most illustrious enforcer during that tumultuous era was Eliot Ness, the "T-man" who toppled Chicago's organized-crime king Al Capone on tax-evasion charges.

The Twenty-first Amendment to the Constitution, repealing Prohibition, achieved ratification with unanticipated speed by 5 December 1933, catching Congress in recess. As an interim measure to manage a burgeoning legitimate alcohol industry, by executive order under the National Industrial Recovery Act, U.S. President Franklin Roosevelt established the Federal Alcohol Control Administration (FACA). The FACA, in cooperation with the Departments of Agriculture and Treasury, endeavored to guide wineries and distilleries under a system based on brewers' voluntary codes of fair competition. The FACA was relieved of its burden - and effectively vanished from history - after just twenty months, when U.S. 
President Roosevelt in August 1935 signed the Federal Alcohol Administration (FAA) Act. The new FAA received a firm departmental assignment: Treasury once more found itself regulating the alcohol industry.

Although Prohibition was officially over, the era's side effects continued for decades to mold the shape of ATF. On 10 March 1934, Justice's Prohibition enforcement duties folded into the infant Alcohol Tax Unit (ATU), Bureau of Internal Revenue, Department of the Treasury. At the same time, the FAA, functioning independently within Treasury, was carrying forward its mandate to collect data, to establish license and permit requirements, and define the regulations that ensure an open, fair marketplace for the alcohol industry and the consumer. In 1940, the FAA merged with the ATU. The FAA Act continues today as one foundation of ATF's enabling legislation.

National dismay over the weaponry wielded so conspicuously by organized crime during Prohibition led to passage in 1934 of the National Firearms Act, followed in four years by the Federal Firearms Act. The newly regulated articles might be firearms, but taxes were involved as ever. The Miscellaneous Tax Unit, Bureau of Internal Revenue, collected the fees. In 1942, enforcement duties for the "Firearms Program" fell to the ATU, which was accustomed to managing controversial industries. In a major Internal Revenue reorganization of 1952, the nearly-century-old Miscellaneous Tax Unit was dismantled. Its firearms and tobacco tax responsibilities went to the ATU. The Bureau of Internal Revenue became the Internal Revenue Service (IRS) we know today. Acknowledging a portion of ATU's new burden, IRS renamed it the Alcohol and Tobacco Tax Division. This incarnation lasted until 1968 passage of the Gun Control Act, which gave to the laboratory, among other things, responsibility for explosives. The division title shifted to Alcohol, Tobacco and Firearms (ATF) Division. Title XI of the Organized Crime Control Act in 1970 (Title XI) formalized ATF Division explosives expertise. In the same year, moved by a growing perception that the IRS's revenue-collecting bias did not reflect ATF Division's enforcement skills, overtures began toward ATF independence.

Treasury Department Order No. 120-1 (originally No. 221), effective 1 July 1972, transferred to ATF from IRS those functions, powers and duties related to alcohol, tobacco, firearms, and explosives. During the mid-1970s, at Treasury's direction, ATF briefly assumed responsibility for wagering laws. That task returned to the IRS in less than 3 years. Throughout 
the 1970s, based on determination that accelerants used in arson, when explosions might occur, meet Title XI's definition of explosives, ATF began demonstrating in court its ability to prove arson. In the Anti-Arson Act of 1982, Congress amended Title XI to make it clear that arson is a federal crime, giving ATF responsibility for investigating commercial arson nationwide.

The Bureau of Alcohol, Tobacco and Firearms (ATF) continues a mutually beneficial interface with its legitimate industries, while refining unique enforcement skills. With developments such as the state-of-the-art Integrated Ballistic Identification System (a computerized matching program for weapons and the ammunition fired from them), accelerant- and explosives/weapons-detection canines, and the Gang Resistance Education and Training (GREAT) program (which gives children the tools to resist membership in violent gangs), ATF leads and supports law enforcement internationally [7-11].

In its first quarter-century ATF has had only 4 Directors: Rex Davis, G.R. Dickerson, Stephen Higgins, and John Magaw. Under the law, the director is appointed by the secretary of the Treasury, and reports to the undersecretary (enforcement). ATF headquarters are in Washington, D.C., although most personnel and many ATF operations are decentralized throughout the country, with a few stations overseas. ATF agents, inspectors, and support staff are involved in investigating some of the most violent crimes in society, in responding to changes occurring in the U.S., and in collecting over $\$ 13$ billion in annual revenue. ATF is a young federal agency, yet it is heir to the whole experience and proud tradition of the United States.

\section{$\underline{\text { Key provisions of U.S. laws regulating firearms }}$}

Federal laws that regulate importation, exportation and transportation of firearms within the U.S. include the Gun Control Act of 1968 (GCA), 18 U.S.C. 44, the National Firearms Act (NFA), 26 U.S.C. 53, and the Arms Export Control Act (AECA), 22 U.S.C. 2778. The powers to implement these legal provisions and oversee their enforcement have been entrusted to the Secretary of the Treasury. The powers to enforce the GCA, NFA, as well as those AECA provisions that concern importation have been delegated by the Secretary to the Bureau of Alcohol, Tobacco and Firearms (ATF). The United States Customs Service has been charged with enforcing those AECA provisions that concern exportation. The objective of the Gun Control Act (GCA) is to impose certain restrictions on the number of individuals eligible to own guns, associated, first, with reaching a certain age; second, with a criminal background; 
and, third, with disability. The GCA was developed and enacted to improve the efficiency of state laws defining the legal framework for the circulation of firearms, enshrining the rule whereby any sales of firearms covering a territory of more than one state shall be effected and licensed to entrepreneurs at the federal level, thus prohibiting sales of firearms by persons who do not hold a license within the state of their location. The National Firearms Act (NFA) contains provisions regarding certain types of firearms, such as machineguns, short-barrelled rifles, shotguns, silencers and explosive (destructive) devices [4, pp. 98-108]. The National Firearms Act stipulates that such firearms must be registered with the indication of their owner, manufacturer and the importer. The Act also provides for taxation of operations with such weapons. The Arms Export Control Act (AECA) (22 U.S.C. 2778) gives the U.S. President powers, in furtherance of world peace and the security and foreign policy of the United States, to control the import and the export of defense articles and defense services, including firearms and ammunition. Under the Arms Export Control Act, permits and licenses to import and export such articles must be available. The Act provides for complete ban on imports to and exports of weapons from certain countries indicated by the government. The powers to control import of weapons under the AECA are held by the Department of the Treasury which delegated them to the Bureau of Alcohol, Tobacco and Firearms. The U.S. State Department and Customs Service implement the AECA export control provisions and supervise compliance with them.

\section{$\underline{\text { Legal and institutional tools to monitor transactions between states }}$}

The Gun Control Act (GCA) stipulates that any firearms transactions performed without the relevant license are illegal (18 U.S.C. $\S 922(a)(1), \S 923(a)$ ). Holders of a federal license entitling to sell firearms are generally prohibited from selling them to persons who do not reside in the state in which the licensee's place of business is located (18 U.S.C. $\S$ 922(b)(3)). As a general rule, unlicensed persons are prohibited from dealing in firearms outside the territory of the state in which they reside or from delivering it to persons located outside the territory of such state (18 U.S.C. $\S 922(a)(1), \S 922(a)(5))$.

\section{Legal and institutional tools to monitor transactions between countries}

U.S. federal laws generally prohibit the importation of weapons regulated by the NFA, such as non-sporting firearms and ammunition, as well as military firearms and ammunition thereto (18 U.S.C. $\S 922(1), \S 925(d)(3) .25$ U.S.C. 5844). 
Under the Arms Export Control Act, any import to the U.S. of defense articles, including firearms and ammunition thereto, as well as unlicensed export thereof from the U.S., are prohibited. An authorization to import or an export license shall indicate the relevant importer and exporter and specify the buyer. Provisions of the Arms Export Control Act (Code of Federal Regulations (CFR) 22, Parts 120-130, and 27 CFR, Part 47) stipulate than natural and legal persons engaged in importing or exporting of defense articles must be registered with the relevant authorities. Such registration is a prerequisite to engaging in the business of importing and exporting these articles [3].

\section{Licensing the business of manufacturing, importing or dealing in firearms in the}

\section{United States}

Under the Gun Control Act (GCA), a license is necessary to engage in the business of importing, manufacturing, or dealing in firearms (18 U.S.C. § 923(a)(1), § 923(a)). A license application must include a photograph and fingerprints of the applicant. An application will be approved if the applicant: 1) is 21 years of age; 2) is not prohibited from transporting, shipping, or receiving firearms or ammunition in interstate or foreign commerce; 3) has not willfully violated any of the CGA provisions; 4) has not willfully failed to disclose any material information required, or has not made any false statement as to any material fact; 5) has, within a state, premises from which he conducts business; and 6) certifies that the business to be conducted under the license is not prohibited by State or local law, and that the relevant application was filed by him with the local law enforcement authorities (18 U.S.C. $\S 923(\mathrm{~d})(1))$. Licenses are issued for a 3-year term. A license may be revoked, and an application for renewal of a license may be denied, if a licensee has willfully violated any provision of the CGA (18 U.S.C. $§ 923(\mathrm{e})$ ). An administrative decision to revoke a license or deny renewal of a license may be appealed at a federal court (18 U.S.C. § 923(f)(3)). Under the AECA, any exportation, temporary importation or temporary exportation of defense articles, including firearms and munition thereto requires a license. An application for a license may be filed by a person registered with the State Department. The application must contain detailed information about the supplied articles, destination, end user and end-use purposes. An import authorization from the end-use country must be attached to the application. Licenses are issued for a 4-year term, subject to subsequent review and audit to establish compliance with the terms of transactions with the license terms [3]. 


\section{Accounting and reporting of manufacturing, importing and dealing in firearms in the United}

\section{$\underline{\text { States }}$}

Licensees must keep records of the weapons on sale and of sold firearms, and must note in their records the buyer's name, age, and place of residence (18 U.S.C. §922(b)(5) and 18 U.S.C. $\S 923(\mathrm{~g})(\mathrm{l})(\mathrm{A}))$. Licensed importers and manufacturers must identify imported or manufactured weapons by means of a serial number to be recorded in the licensee's accounts (18 U.S.C. § 923(i)). Licensees are required to respond promptly to ATF requests concerning the origin of firearms (18 U.S.C. $\S 923(\mathrm{~g})(6))$. Furthermore, regular reports are to be provided to ATF of two or more units of personal firearms sold at one time or during any five consecutive business days (18 U.S.C. $\S 923(\mathrm{~g})(3)$ ). Licensees who discontinue their business are required to deliver their records to ATF (18 U.S.C. § 923(g)(4)). These requirements enable the attainment by ATF of one of the Gun Control Act's key objectives: assist government officials charged with law enforcement functions, local authorities, as well as foreign law enforcement authorities in the quick determination of the origin of firearms used in the commission of crimes.

Conclusions The U.S. Government does not keep track of licensees' transactions with firearms, other than the above reporting delivered to the government upon discontinuation of the licensee's business, reports of two or more units of personal firearms sold, and reports of the origin of firearms. Processing the information contained in these reports enables identification of key areas of activities in the matters of identifying illegal suppliers of weapons and sources of firearms sold within the United States. 22 CFR § 122.5 stipulates that a licensee must maintain records concerning all transactions performed by it under export, temporary import or temporary export licenses for a period of five years. Such records must be provided to a U.S. Customs Service official upon his request. Computer record of such transactions is also maintained by the U.S. State Department and at customs terminals [5, pp. 90-100].

\section{References}

1. David P. Currie. The Constitution of the United States. A Primer for the People. Kyiv, Veselka, 1993, pp. 19-21.

2. The Bureau of the control of alcohol drinks, tobacco products and fire-arms in the United States of America (ATF). 07/01/1972. 
3. A. S. Matsko, I. V. Boiko. Weapons: Buying, Storing, Using. Compiled Statutes. Kyiv, Yurinkom, 1998, 304 p.

4. Ballistics: A Firearms Research. Forensic Weaponology. A Handbook (in collaboration). Kyiv, BeeZone, 2003, pp. 98-108.

5. Weaponology: Legal Framework of Firearms Circulation. A Monography (in collaboration). Kyiv, BeeZone, 2004, pp. 90-100.

6. Сучасні можливості дослідження харчових продуктів. Modern features of food research. URL: http://elar.naiau.kiev.ua/jspui/handle/123456789/2999

7. Systemna informatyzacija dijal'nosti organiv diznannja ta dosudovogo slidstva: systemologija, kibernetyka, konsolidovana analityka, bezpeka. [System informatization of activity of bodies of inquiry and pre-trial investigation: systemology, cybernetics, consolidated analytics, safety.]

URL:http://elar.naiau.kiev.ua/jspui/handle/123456789/4336

8. Informacijne suspil'stvo: upravlinnja, pravo, tehnologii', bezpeka. [Information society: governance, law, technology, security.]

URL:http://elar.naiau.kiev.ua/jspui/handle/123456789/4337

9. Informacijna analityka $v$ jurysprudencii': avtomatyzovani systemy $i$ tehnologii'. [Information analyst in jurisprudence: automated systems and technologies.]

URL:http://elar.naiau.kiev.ua/jspui/handle/123456789/4335

10. Bezpeka informacijnoi' analityky: strategija, taktyka, mystectvo, tehnologii'. [Security of information analytics: strategy, tactics, art, technology.]

URL:http://elar.naiau.kiev.ua/jspui/handle/123456789/4334

11. Kryminalistychna analityka: informacijni systemy, integrovani banky danyh, elektronni merezhi. [Criminalistics analysis: information systems, integrated data banks, electronic networks.] URL: http://elar.naiau.kiev.ua/jspui/handle/123456789/5463

\section{Translation of references to the original language}

6. Сучасні можливості дослідження харчових продуктів. Modern features of food research. URL: http://elar.naiau.kiev.ua/jspui/handle/123456789/2999

7. Системна інформатизація діяльності органів дізнання та досудового слідства: системологія, кібернетика, консолідована аналітика, безпека. System informatization of activity of bodies of inquiry and pre-trial investigation: systemology, cybernetics, consolidated analytics, safety.

URL:http://elar.naiau.kiev.ua/jspui/handle/123456789/4336

8. Інформаційне суспільство: управління, право, технології, безпека. Information society: governance, law, technology, security.

URL:http://elar.naiau.kiev.ua/jspui/handle/123456789/4337

9. Інформаційна аналітика в юриспруденції: автоматизовані системи і технології. Information analyst in jurisprudence: automated systems and technologies. URL:http://elar.naiau.kiev.ua/jspui/handle/123456789/4335 
10. Безпека інформаційної аналітики: стратегія, тактика, мистецтво, технології. Security of information analytics: strategy, tactics, art, technology. URL:http://elar.naiau.kiev.ua/jspui/handle/123456789/4334

11. Криміналістична аналітика: інформаційні системи, інтегровані банки даних, електронні мережі. Criminalistics analysis: information systems, integrated data banks, electronic networks.

URL:http://elar.naiau.kiev.ua/jspui/handle/123456789/5463 